\title{
Promotion of Atheism as a Principle of the Communist Ideology - Case Study: Romania
}

\author{
By Alin Goron*
}

\begin{abstract}
The Communist ideology called for the denial of Christianity as a form of "mysticism" filled with "superstitions", but particularly as one of the factors that impeded social, economic and cultural progress. Scientific socialism, however, was meant to awaken class consciousness, setting Romanian society on a path towards true modernity. Thus a real battle ensued on the ideological front between two entities, the secular and ecclesiastical authorities, arising from the divide between traditional religious beliefs and atheist Marxism. The actions of the authorities against religious propaganda included both practical measures, which involved activities that filled the free time of the villagers, but also coercive measures consisting in political pressure or arrests. In spite of the communist regime's efforts to impose its own cultural agenda, the effects were long overdue, with rather modest results. Romania's forced development was faced with some inherent problems of the process of modernization and industrialization. The forced imposition of a foreign ideology to a conservative Eastern European area relying on obsolete mindsets, a society where 80\% of the population lived in rural areas as of the end of the Second World War, required a longer period of time than the regime had originally planned.
\end{abstract}

"Religion is the sigh of the oppressed creature, the heart of a heartless world, and the soul of soulless conditions. It is the opium of the people."1 Only the second part of this famous statement of Karl Marx is usually quoted. However, the antagonism between Christianity and Marxism did not remain the same during the evolution of the two concepts, which thus distinguishes several stages.

In 1843, a group made up of German progressive intellectuals arrived in Paris. Some of the most significant members included Arnold Ruge, Moses Hess and Karl Marx. In his diary, Ruge recalled in astonishment how their French counterparts agreed with most of the ideas expressed, with just one exception: the atheism embraced by the German group. Lamennais, Blanc or Cabet were Christians who saw communism as the forefather of Christianity, or its pragmatic incarnation to be precise, and Jesus as the first communist. However, this concept did not last long, as the Christian Churches became ever more conservative, peaking in the Syllabus Errorum of Pope Pius IX, which condemned liberalism.

The drive to resume the dialogue between the two dogmas came from Christians, particularly the Protestant theologians from Germany. ${ }^{2}$ Later after World War II, their relationship with the communist regime in East Germany became strained, culminating in the events of 1989, sometimes referred to as the

"PhD Student, "1 December 1918" University, Romania.

1. Robert R. King, "Religion and Communism in the Soviet Union and Eastern Europe," BYU Studies Quarterly 15, no. 3 (1975): 323-347.

2. David McLellan, Marxism and Religion (Houndmills, Basingstoke, Hampshire and London: MacMillan Press, 1987), 1-2. 
"Protestant Revolution", thus emphasizing the important political role of this Church. ${ }^{3}$

Returning to Marxist dogma, whose basic principle consists in the relationship between structure and superstructure, Christianity falls within the superstructure, and is thus outside reality. According to this paradigm, we can relate to the fierce critique of religion in Marxist writings. ${ }^{4}$

To expand somewhat the topic of the relationship between Christianity and Marxism, I would like to recall the vision of F. Engels on this relationship, which was later embodied in the Latin American version.

"Christianity, like every great revolutionary movement, was made by the masses", wrote Friedrich Engels. Thus, primary Christianity represented a spiritual-religious expression of the oppressed that fought for emancipation. Therefore, similarly to Socialism in the modern era, Christianity exercised control over the masses, since it offered them the awareness of being part to a social category deprived of rights, which was opposing a ruling class that only sought to perpetuate the current status quo. ${ }^{5}$

The overlapping of the religious theme with revolutionary socialism is an old topic, but one that still remains current today. The similarities between the two are obvious to a certain extent, where the two theories of creationism and evolutionism are set one against the other. In this matter, I note the study of Michael Lowe and Mariana Ortega Berna dedicated to the history of the communist movement in Latin America. ${ }^{6}$

But religion also played an important role in building the nation-states of Central and Eastern Europe in the interwar period, on the ruins of ancient empires. In the multinational universe of Greater Romania, the idea of nation and the building of the social, ethnic and cultural Romanian identity in the new geographical space revolved around the religious imaginary of the "sacred nation."7

The 1939 New York World's Fair also included a Romanian pavilion with an inscription in large letters on a marble column: "Romania has over 20 million people united unto language, tradition and culture." In 1940, shortly after this

3. Peter Molloy, The Lost World of Communism, An Oral History of Daily Life behind the Iron Curtain (BBC Books, 2017), 134.

4. David McLellan, Marxism and Religion, 1987, 1-2.

5. K. Mathew Kurian, "Marxism and Christianity," Social Scientist 2, no. 8 (1974): 321.

6. Michael Löwy and Mariana Ortega Brena, "Communism and religion: José Carlos Mariátegui's Revolutionary Mysticism, Latin American Perspectives," Reassessing the History of Latin American Communism 35, no. (2008): 71-79.

7. Zsuzsánna Magdó, "Mass Enlightenment, Atheism and the Romanian Socialist Nation: The Society for Dissemenation of Culture and Science, 1949-1963," in Politici Culturale și Modele Intelectuale în România, ed. Lucian Năstasă and Dragoș Sdrobiș (Cluj-Napoca: Editura Mega, 2013), 121. 
event, Romania lost large parts of its national territory to the Soviet Union, Bulgaria and Hungary ${ }^{8}$.

The national and cultural universe that brought Romanians together under the umbrella of the largest territory they had ever known, with the major contribution of religion, was now collapsing. This status-quo has never been restored after the end of the Second World War.

In this study, I am not seeking to consider the institutional relationship between the Church and the State, since the subject has been long debated so far' ${ }^{9}$. What I will follow is the transformation of the Romanian society after the Second World War under the leadership of the new communist regime. I am particularly interested in how the atheist ideology of communism came into being and what was the response of an agrarian and conservative society marked by a strong religious sentiment, where the left movement never truly had the support of the masses. I will be then going down to the microsocial level to reveal attitudes, contradicting reactions, but also changes in power structures.

I am also capturing descriptions Christian expressions in the Romanian space, with a differentiated emphasis on Catholics, evangelicals and Protestants ${ }^{10}$ in terms of exposure and analysis, also reflecting on measures taken by the authorities under the umbrella of the new ideological reality.

The documentary research was based on resources such as as Central National Historic Archives, the collections of Sedition and Propaganda, Ministry of Propaganda, The Society for the Promotion of Science and Culture, and the resources of the Alba National Archive Service, the Romanian Workers' Party fund. I also included several articles from the most important journal of the Communist regime, the Scânteia newspaper.

The subject was approached by many researchers during the post-war years. Thus, Richard T. D George and James P. Scanlan ${ }^{11}$ discussed various forms of Marxist philosophy in Eastern European states, but also the relationship between Communist regimes and the Church. Later, Trond Gilberg spoke about the

8. Irina Livezeanu, Cultural Politics in Greater Romania: Regionalism, Nation Building, and Ethnic Struggle, 1918-1930 (Cornell University Press, 1995), 9.

9. See Cristian Vasile, Biserica Ortodoxă Română în Primul Deceniu Comunist (The Romanian Orthodox Church during the First Communist Decade) (București: Editura Curtea Veche, 2013); Vasile, Intre Vatican si Kremlin. Biserica Greco-Catolică în Timpul Regimului Comunist (Between Vatican and the Kremlin. The Greek Catholic Church during the Communist Regime) (București: Editura Curtea Veche, 2013); Lucian N. Leuștean, Orthodoxy and the Cold War Religion and Political Power in Romania, 1947-1965 (Basingstoke, Hampshire and New York: Palgrave Macmillan, 2009).

10. In Romania, the term of neoprotestants is used to designate the following cults: baptists, pentecostals, adventists or Jehova witnesses. I will use the terms protestants.

11. Richard T. D. George and James P. Scanlan, Marxism and Religion in Eastern Europe (Dordrecht-Holland and Boston: D. Riedel Publishing Company, 1974). 
relationship between nationalism, then between Nationalism and Communism in a volume edited by Pedro Ramet. ${ }^{12}$

Robert R. King also noted that one reason for the divide between Christianity and the Communist regime in Eastern Europe was the struggle for influence over peoples' faiths. Therefore, the contradiction between the two views led to the emergence of ambivalence between the political and ideological motivations of the campaigns against the Christian religion. ${ }^{13}$

The rift between Communist regimes with religion was consistent with the Soviet version of Socialism, particularly in the 1930s, when Magnitogorsk became the model of a new city inspired by a the new ideological meaning, founded not on ignorance or superstition, but on education and science. The city was to become a symbol of hope and progress. ${ }^{14}$

Magnitogorsk became the first city to ban the building of churches in a formerly Christian country. The newspapers rarely mentioned religious holidays and practices such as the Ramadan or the Orthodox Christmas or Easter. ${ }^{15}$

More recent studies, such as that of Zsuzsánna Magdó, ${ }^{16}$ focusing on the role of the "Society for the Promotion of Science and Culture" in the education of the masses, whose mission was to promote science at the expense of religious education, emphasizes the failures of the Communist system in its early stages, i.e. before the national-communism, whose causes were found in the assignment of tasks to a large number of organizations of the Romanian Workers' Party. ${ }^{17}$

In this research, I used both theoretical methods, i.e. the discourse and comparative analysis of official documents of the Romanian Workers' Party or the main newspaper of the regime, but also empirical methods, i.e. observing the social transformations of post-Communist Romania.

Beginning with 1948, the monarchy was abolished in Romania, and power was taken over de facto by the Communist authorities. The Romanian realities revealed a deeply agrarian society, where nearly $80 \%$ of the population lived in rural areas.

12. Trond Gilberg, "Religion and Nationalism in Romania," in Religion and Nationalism in Soviet and East European Politics, ed. Pedro Ramet (Durham, N.C.: Duke Press Policy Studies, 1984), 170-187.

13. King, Religion and Communism in the Soviet Union and Eastern Europe, 1975, 325.

14. Stephen Kotkin, Magnetic Mountain (Berkeley, Los Angeles, London: University of California Press, 1995), 108.

15. Ibidem, 188.

16. Zsuzsánna Magdó, "Mass Enlightenment, Atheism and the Romanian Socialist Nation: The Society for Dissemenation of Culture and Science, 1949-1963," 2013, 120-157.

17. I will use the PMR abbreviation or the term of "party", since it became the only political party in the Romanian People's Republic after 1948. Until 1948 it was referred to as the "Romanian Communist Party", and was outlawed from 1924 and during the interwar period. It became legal after the coup of 23 August 1944. 
The Cult Law, adopted on August 4, 1948 and enacted by Decree no. 177, provided for wide religious freedom, which also included Protestant cults, whose activity had been banned during the Antonescu regime. ${ }^{18}$ Thus, the first article stated that "The state guarantees the freedom of conscience and religious freedom throughout the Romanian People's Republic. Anyone may belong to any religion or embrace any religious faith, provided that its exercise is not contrary to the Constitution, security and public order or morality."19

In order to function, however, the cults needed the approval of the Praesidium of the Grand National Assembly, ${ }^{20}$ following a proposal by the Government and a recommendation from the Ministry of Cults. The appointment of the leaders of the cults followed the same procedure, which ended with taking an oath before the ministry that had offered the recommendation.

By comparison, the Soviet Constitution of 1936 offered "freedom for religious manifestations, but also freedom to engage in anti-religious propaganda, for all citizens."21 Such a paragraph was missing in both the 1948 Constitution and the Cult Law of the same year, while several provisions left room for interpretation, as, for example, Article 6, which read that "Religious cults are free to organize and may function freely if their practices and ritual are not contrary to the Constitution, security or public order and morals."22

Communist ideology identified both religious dogmas and the Church as the main culprits for the economic, social and cultural underdevelopment of most of the masses. Scientific socialism, on the other hand, was meant to awaken class consciousness, setting Romanian society on a path towards true modernity. The great dilemma boiled down to the methods by which the regime was to impose its own vision in one of the most religious states in Central and Eastern Europe. ${ }^{23}$ For the Romanian Workers' Party, which took power with the support of the Soviets, this was a huge challenge. This was followed by the training of party cadres, who were tasked with educating the masses, chiefly among which was thwarting religion. Despite the freedoms granted by the Cult Law, state control became almost total, compounded at the same time by a permanent competition

18. The General Ion Antonescu ruled Romania from 1940 to 1944, his regime being considered a military dictatorship. See Dennis Deletant, Hitler's Forgotten Ally: Ion Antonescu and His Regime, Romania 1940-1944 (Houndmills, Basingstoke, Hampshire and New York: Palgrave MacMillan, 2006).

19. http://www.anrp.gov.ro/. [Accessed 6 May 2020.]

20. The Great National Assembly represented the unicameral legislative power of the Romanian People's Republic and later of the Socialist Republic of Romania, during 19471989.

21. https://www.departments.bucknell.edu/. [Accessed 19 May 2020.]

22. http://www.anrp.gov.ro/. [Accessed 19 May 2020.]

23. Institutul Cultural Roman, Religion and Identity in Interwar Romania: Orthodoxism. Retrieved from: https://www.icr.ro/pagini/religion-and-identity-in-interwar-romania-orthodoxism. [Accessed 19 May 2020.] 
between different local or state power structures. While the Orthodox Church was tacitly tolerated by the regime, with the exception of some clerics, the GreekCatholic Church ${ }^{24}$ was to return to the Orthodox Church, with the opponents subjected to pressures and arrested, while the Roman Catholic Church was to abide by the Vatican. Protestant cults received special attention from the regime and were under constant pressure, particularly the Jehovah's Witnesses or the Adventists who rejected military service.

\section{Catholics and Protestants}

On the path to asserting their own ideological agenda, the Communist authorities launched a broad campaign to monitor religious cults and their activities. It targeted mostly Catholics and Protestants, although the Orthodox did not escape the regime's supervision either. These actions emphasized the fierce competition between the two opposing entities, the Communist regime and the Church authorities, for the minds of the people. The central authorities repeatedly mentioned that religious processions and any other cult activities hindered the proper conduct of agricultural work, and became a barrier to economic recovery efforts.

The official reports dedicated a separate section to these issues, but the events were described with errors and confusion, sometimes deliberately. PMR documents highlighted the regions of Transylvania, Banat and Bukovina as having the largest Catholic and Protestant religious communities. ${ }^{25}$ The deliberate ambiguity of official accounts was due either to the poor training of the party cadres, or to the purposeful inclusion of arguments meant to suggest false conclusions and assumptions, in order to subvert certain religious cults.

24. The Romanian Church United with Rome came about following an unification of a large share of clerics and believers from the Transylvanian Orthodox Metropoliswith the Church of Rome. Some of the believers refused to join, but most of them stayed faithful to the united bishops. Based on the 1930 census data, $31.1 \%$ of the Transylvanian population was Greek-Catholic, while $27.8 \%$ was Orthodox. In Crișana-Maramureș, $36.8 \%$ of the population was Orthodox and $25.2 \%$ Greek-Catholic, while in Banat, $56.1 \%$ of the population was Orthodox and 3.6\% Greek-Catholic.

25. Transylvania, Banat and Bukovina are three historic provinces that were formerly part of the Austrian Empire, then of the Austro-Hungarian Empire. It included significant ethnic minorities such as Hungarians and Germans, as well as Orthodox, Greek Catholics, Roman Catholics, Calvinists, Lutherans, Reformed and Neo-Protestants, with the latter arriving in the early twentieth century. During the Austro-Hungarian monarchy, scores of Translyvanian Romanians left to the United States. 
Given the lack of activities in cultural homes, ${ }^{26}$ the priests offered an alternative in the religious education for the masses (Sălaj County), which consisted of church songs, with the authorities thus blaming the cultural homes who were said to be led by "inappropriate elements" who made the homes available to the clergy for religious activities."27

A real ideological and political struggle was thus beginning, where the Communist regime initially struggled with lack of funds and party cadres required for organizing mass cultural activities in rural areas, which offered wide room for manoeuvre to Church authorities in their effort to maintain their legitimacy. Another example is that of the Făgăraș county, where in the absence of cultural initiatives of cultural homes, the priests would organize Church choirs. $^{28}$

The "reaction"29 was accused of distributing religious materials with the help of US-funded missionaries, which was deemed as propaganda action. ${ }^{30}$ Article 42 of the Cult Law stated that "Aid or offerings received from abroad by domestic religious cults or sent by them abroad shall be controlled by the State."31 This article was intended to prevent the provision of support by the Vatican and the US. The "religious sects" 32 were blamed for spreading apocalyptic rumours, which unsettled the peasants and at the same time thwarted agricultural activities. ${ }^{33}$ The billboard from a commune ${ }^{34}$ (Botoșani county) displayed an announcement which predicted the coming of God on Earth. ${ }^{35}$

With the tacit consent of some Orthodox priests in the commune of Răchitosu (Putna County), young people were told about the superiority of the Catholic religion and were urged to join the "Army of the Lord"36. In the

26. The cultural homes had been established during the interwar period, by an initiative of the "King Carol" Royal Foundation, and were taken over by the Romanian People's Republic after 1947. They operated mostly in rural areas and were the main institutions tasked with cultural activities such as conferences, balls, theatre plays, movies or contests.

27. ANIC, collection C.C of P.C.R, Propaganda and Sedition Section, file 15/1948, f. 220.

28. Ibidem, file 18/1948, f. 18-19.

29. A term used by the communist regime to designate both the regime opponents and the social groups that did not fit the new ideological tenets.

30. Collection C.C of P.C.R, Propaganda and Sedition Section, file 4/1948, f. 13.

31. http://www.anrp.gov.ro/. [Accessed 19 May 2020.]

32. The name was used by Communist authorities for protestant cults, particularly the Jehova's witnesses and the pentecostals or adventists.

33. Collection C.C of P.C.R, Propaganda and Sedition Section, file 2/1949, f. 174-175.

34. Commune (from the French commune; plural "communes") is a basic economicadministrative unit made up of one or several villages.

35. Ibidem.

36. The "Army of the Lord" was a reformist movement within the Romanian Orthodox Church which emerged in 1923, at the initiative of the Transylvanian priest Iosif Trifa. 
Nămoloasă commune (Galați county), a "chiabur"37 became the pastor of a "sect" with the support of the priest, and in several communes such as Ruginești, Păulești or Movilița, the activities of the "cults" increased significantly. ${ }^{38}$ These are just some of the situations where the PMR members who dealt with the propaganda action mixed the information in order to discredit the religious cults as a whole. The Catholic religion had nothing to do with the "Army of the Lord" organization, which belonged to the Orthodox Church, but it is even less likely the Orthodox clergy would support Protestant cults.

Many young people went from the Orthodox to the Adventist cult (Tecuci county), in an attempt to evade military service. ${ }^{39}$ The 1948 Cult Law stated in Article 37 that, "If at least $10 \%$ of the believers in a local cult pass to another cult, the local religious community of the abandoned cult shall forfeit its assets proportionally with the number of leaving believers, with such assets being transferred by law to the local cult embraced by the new believers." ${ }^{40}$ The law aimed to ensure the transition of large numbers of believers to Orthodoxy, with the assets of the cult being transferred to the Orthodox Church. The existence of many religious denominations also divided the believers and implicitly hindered the regime in imposing its control and authority.

The priests (in Suceava and Bacău counties) were accused of holding too many services in a week (four or more), thus preventing the peasants from engaging in agricultural work, and Catholic priests (Faraoani and Doja communes, Bacău county) forbade believers from engaging in political activities. A member of the UFDR ${ }^{41}$ withrew from the organization, and the number of PMR member dropped due to the arrest of two priests ${ }^{42}$. Since the communist regime was in a process of earning its legitimacy, the PMR needed as many members as possible, and such situations were unacceptable. The consequences were usually felt by the clergy.

At the "Ștefan cel Mare" High School (Suceava), Protestant students were accused of reading the Bible at night, hidden under pillows, and Jewish female students refused to come to school or write on Saturdays. ${ }^{43}$ In such a case, control over young people became essential for the further evolution of the regime, and secularization of education becomes a priority.

Most of the problems continued to occur in Transylvania, which held significant Protestant and Catholic communities. On May 1st, the priest in the Dobra commune, Deva county, did no comply with the religious service period

37. A term describing well-off peasants, similar to the "kulak" in the Soviet vocabulary.

38. Collection C.C of P.C.R, Propaganda and Sedition section, file 2/1949, f. 174-175.

39. Ibidem.

40. http://www.anrp.gov.ro/. [Accessed 6 May 2020.]

41. Romanian Union of Democratic Women.

42. Collection C.C. of P.C.R, Propaganda and Sedition Section, file 2/1949, f. 174-175.

43. Ibidem, f. 189. 
initially agreed with the authorities, attempting to prevent the villagers from taking part to events organized by the authorities. The villagers (Năsăud county) were invited to various lectures held by protestant cults on Saturdays, thus hindering farming works. The priest Ioan Isaac (Săliște commune, Sibiu county) urged the villagers to take part in religious celebrations spanning six days, while in the Făgăraş county, the priests would organize prayers for rain. ${ }^{44} \mathrm{~A}$ pretext often used to minimize religious cult activities was that of not hindering farming works. Absent leisure alternatives for the villagers in the wake of taking power, the authorities were limited to enforcing coercive measures with the help of party propaganda officials.

The protestant cults found ways to remain active by organizing religious debates in forests (Târnava Mică County), with young people agreeing to take part in the cultural activities of the authorities on condition they were allowed to sing religious songs. A religious leader was also named, a certain Cozma, who travelled from Brașov county to support the "sects."45

The religious nerve centre of Jehovah's Witnesses (Mureș County) was deemed a threat by the authorities because, despite their meetings had been banned, they still met in small groups of 7-8 people. ${ }^{46}$ Loopholes in the same Cult Law were opened to abuse, and Jehovah's Witnesses were targeted by the authorities because of their refusal to perform military service.

A significant number of believers of this cult were found in the Niraj Valley (Mureș county), because their leader, Marton Magyaros, ${ }^{47}$ was based in Târgu Mureș.48 Party members would hinder the activities of certain religious organizations in places such as Chiherul de Sus, Sovata or Reghin (Mureș county). However, despite regime pressures, Protestant cults found ways to carry on with their activities. ${ }^{49}$

The regime's attention was also aimed at the Greek-Catholic priest, mainly those who refused to change to Orthodoxism and held clandestine masses. They prepared the young people from neighbouring areas (Brașov county), for the

44. Collection C.C of P.C.R, Propaganda and Sedition section, file 18/1949, f. 6-7.

45. Ibidem.

46. Ibidem.

47. Regional administrative seat.

48. Collection C.C of P.C.R, Propaganda and Sedition Section, file 18/1949, f. 54.

49. Collection C.C of P.C.R, Propaganda and Sedition Section, file 18/1949, f. 54. 
religious pilgrimage from Ciuc, ${ }^{50}$ while in Ditrău commune (Mureș county), the Catholic priest announced the participation of party organizations at the Easter service $^{51}$. The attempt to legitimize the regime in the eyes of the faithful by participating in religious life has a double meaning. On one hand, the priest attempted to gain support from believers and the goodwill of the authorities.

On May 1, the Catholic Church would organize services for the sanctification of wheat, and a priest from Remetea (Mureș County) rang the bells to call parishioners to the service; when they failed to arrive, he approached the people who participated in party activities and convinced 50 villagers to join him in service $^{52}$. Such actions were seen by the regime as provocations aimed at diverting people from Labour Day events.

The rural collective mind, still prone to mystical beliefs, remained attached to traditional values and strongly rejected the new atheistic ideology. This mystical character combines both pre-Christian and post-Christian elements ${ }^{53}$.

Official documents relay various miracles claimed by the believers. The claim that a woman was turned into a donkey (Trei Scaune county) caused panic among the peasants, who started to refuse working the field on holidays ${ }^{54}$.

A worker established a new "sectă" (Prahova county), named the "Tudorists", while in Bobocu (Buzău county), a woman was venerated as saint and people came in hundreds to see her. She was subsequently declared mentally insane and committed to a mental hospital. The locals protested because the continued drought was attributed to that woman's disappearance. The authorities would react by public ${ }^{55}$ "denunciations" 56 .

In Odorhei county, during the Catholic Easter, the clergy organized a pilgrimage to the Satu Mare commune that was attended by more than 1,500 people. A woman, also said to be insane, foretold the future there ${ }^{57}$.

50. The pilgrimage from Șumuleu Ciuc is first ad foremost a religious event, held for several days during the Catholic Pentecost, and is also a ritual merging Roman Catholic liturgy with popular religious beliefs. The theologic foundation of the Șumuleu Ciuc pilgrimage is the veneration of Virgin Mary. The Șumuleu Ciuc pilgrims express their gratitude to Virgin Mary by means of donations and plaques, and at the same time pray to her for protection against the vagaries of life (Maria advocata, Maria mediatrix), https:// patrimoniu.ro/images/imaterial/Pelerinajul-de-la-Sumuleu-Ciuc.pdf. [Accessed 9 May 2020.]

51. Collection C.C of P.C.R, Propaganda and Sedition Section, file 18/1949, f. 6-7.

52. Ibidem.

53. See Kenneth Jowitt, Social Change in Romania, 1860-1940, A Debate in Development of a European Nation, Institute of International Studies (Berkeley: University of California, 1978).

54. Collection C.C of P.C.R, Propaganda and Sedition Section, file 18/1949, f. 6-7.

55. The term of "denunciation" had been taken over from the Legionary Movement's terminology, a Romanian interwar right-wing party, and later used by Communist authorities to expose regime enemies.

56. Collection C.C. of P.C.R, Propaganda and Sedition Section, file 18/1949, f. 72.

57. Ibidem, f. 123-125. 
In Morislovești commune (Baia county), during the popular assessors elections, several people, including PMR members, demanded to bring a saint woman to the village, thus disturbing the peace. ${ }^{58} \mathrm{~A}$ former member of the party with mental problems was venerated as a saint, and religious processions were organized with the support of the clergy to worship him. He was also accused of anti-communist propaganda. ${ }^{59}$

A token of the cultural gap between urban and rural areas is the statement of an employee of the Triaj factory in Brasov, who said that she "believes in God, but does not believe that saints appear on the windows of the most depraved women in the neighbourhood."60

Building miracles or the veneration of people as saints was part of the daily life of the postwar era, especially in rural areas, being based on the religious mysticism otherwise characteristic of the Romanian space. The regime would cleverly use such cultural and social realities to build an ideological discourse.

In the Răducăneni commune (Fălciu county), during Easter celebrations, the Catholics organized religious processions by moving icons and the church choir through the village to mobilize the villagers, while the Protestants were accused of using drought to spread false rumours. ${ }^{61}$ It was rumoured that 54 countries were at war, with the endorsing of military records for officers and soldiers being blamed on a general mobilization Botoșani county. ${ }^{62}$ The rumours forecasting an imminent catastrophic military conflict became prevalent during the postwar period. Some representatives of religious cults spread such information in order to attract believers, although it is difficult to tell whether such moves were deliberate or based on own convictions.

The party members tasked with propaganda had to follow closely the religious manifestations on Christian holidays, such as Easter, with the mission to "thwart any enemy provocations from class enemies." ${ }^{3}$ For that purpose, secular and religious activities were organized in order to attract the "working people". "The trade unions and the UTM will organize trip for the working people on Easter days. Such trips will be supervised by activists to prevent any unhealthy manifestations."64

"As regards winter holidays, large parts of the masses are ingrained with certain customs and rites. Party organizations, with the support of mass organizations and cultural institutions, will give these events a progressive content reflecting the spirit of class struggle, dissemination of the conquests of the working people on the path to strengthening popular democracy and building

58. Collection C.C. of P.C.R, Propaganda and Sedition Section, file 18/1949, f. 107-108.

59. Ibidem.

60. Ibidem, f. 123.

61. Collection C.C. of P.C.R, Propaganda and Sedition Section, file 18/1949, f. 33.

62. Ibidem, f. 34 .

63. Ibidem, file 2/1950, f. 74 .

64. Ibidem, f. 75 . 
socialism in our country."65 As Sonja Luehrmann also noted, several post-war communist parties had to accept a policy of compromise in their relations with religious communities. With the exception of Albania, which declared itself the world's first atheist state, all communist governments provided a legal framework for the conduct of certain religious activities, but kept them under close scrutiny. ${ }^{66}$

During 22-29 May (Timiș and Buziaș counties), young people would celebrate the "youth week" by not going to work, and the baptist church of Timișoara had 300 young people and a publication called Christian Baptist Guidelines, ${ }^{67}$ printed in Bucharest. The UFDR meetings (Arad county) were also attended by "shakers"68 who obstructed the activities.

The Catholic Easter saw the organization of religious processions also attended by some party members, with more than 4,000 participants. A GreekCatholic priest tried to attract Orthodox believers, and Protestants were accused of having thrown church bells in fountain wells or sacrificing animals to stop the drought. ${ }^{69}$ As the party was unable to ensure the ideological purity of its own members, it has to lead both an internal and an external fight. Under such circumstances, the regime's only solution was to adapt to the existing realities. This will combine methods such as publicly shaming cults accused of immoral behaviour, like orgies or animal sacrifices, supplemented by growing surveillance practices.

The participation of villagers in party activities was carefully recorded by the authorities, which recalled that during a representation by cultural teams (Oradea county), no one left although the bells were ringing in the church. ${ }^{70}$

In the north of the country (Iaşi county), "sects" organized night religious processions, while priests used icons during religious events, and in Bacău county the Catholic clergy enforced an order of Bishop Durcovici, ${ }^{71}$ threatening excommunication to those who requested the service be performed in Hungarian. Protestant cults (Botoșani County) organized an activity attended by over 500

65. Ibidem, file 37/1948, f. 30.

66. Sonja Luehrmann, "Antagonistic Insights: Evolving Soviet Atheist Critiques of Religion and why they Matter for Anthropology," in Social Analysis: The International Journal of Anthropology 59, no. 2 (2015): 97-113.

67. See https://istorieevanghelica.ro/indrumatorul-crestin-baptist/. [Accessed 9 May 2020.]

68. Another term used by Communist authorities for protestant cults.

69, Collection C.C. of P.C.R, Propaganda and Sedition Section, file 18/1949, f. 88.

70. Ibidem, f. 97-98.

71. http://www.durcovici.ro/. [Accessed 9 May 2020.] 
people, addressed to Pastor Alexandru Panaitescu, ${ }^{72}$ who recommended the faithful to refrain from political activities. In the end, religious materials were distributed that had been brought from Ploiești, the latter being recognized as a place of origin for such materials.

At a meeting organized by the Hungarian People's Union (UPM, $)^{73}$ the priest raised the issue of equality between people, with quotes from the Bible, and the end requested a place of worship for the religious services. ${ }^{74}$ Members of Protestant communities (Mureș County) predicted, according to biblical writings, great periods of social unrest followed by the recovery of lost fortunes. Against this background, the number of Protestants rose to 1,000 members in the neighbouring county of Târnava Mare..$^{75}$

In Miraslău (Alba County), the priest was accused of boycotting a UFDR meeting, while in Săliștea commune (Făgăraș county), the leader of the religious community told the parishioners that Lenin and Stalin were faithful Christians and that priests were not exactly "chiaburs" as the Communist authorities claimed due to the clergy rejecting the agrarian reform. ${ }^{76}$ This attempt to legitimize the regime, coming from representatives of the Church authorities, can be attributed to the awareness of the new social and political realities, and obviously to an attempt to find appropriate methods for coping with the new ideology. The same can be said of the decision of some young Protestants to take part in activities of cultural homes. ${ }^{77}$ The students of the Faculty of Theology from Suceava would travel to rural areas to hold conferences on religious subjects, or plays and poems. Such activities took place on Sundays, while the middle of the week was left out to scientific meetings. ${ }^{78}$

In the Jiu Valley mining region, the PMR organization was reprimanded for failing to take action against a Protestant party member who was organizing religious activities. ${ }^{79}$ The encouragement of whistleblowing became one of the

72. Decree no. 883 of 9 November 1946 offered cult status to Evangelical Christians in Romania, similar to other faiths. The same legislation also approved the Cult's internal statutes. It established the Union of Romanian Christian Evangelical Assemblies, based in 18 street, Ploieşti, at the second floor of Alexandru Panaitescu's house, where it functioned until 1958, at which time it was moved to Bucharest, apud https://roev.wordpress.com/ 2015/07/01/crestinii-dupa-evanghelie-115-ani-in-romania-repere-cronologice-bogdanemanuel-radut/. [Accessed 9 May 2020.]

73. See Stefano Bottoni, Transilvania Roșie. Comunismul Român şi Problema Națională 1944-1965 (Red Transylvania. Romanian Communism and the National Problem 19441965) (Cluj-Napoca: Editura Institutului Pentru Studierea Problemelor Minorităților Naționale, 2010), 69-74.

74. Collection C.C. of P.C.R, Propaganda and Sedition Section, file 18/1949, f. 123.

75. Ibidem, f. 123-125.

76. Ibidem.

77. Ibidem, f. 141.

78. Collection Ministry of National Propaganda, file 2937/1946-1947, f. 3.

79. Collection C.C. of P.C.R, Propaganda and Sedition section, file 18/1949, f. 123-125. 
regime's go-to methods, with the repercussions being directed at both the accused and the abettors.

The reactions from the Catholic communities, particularly in predominantly Hungarian-speaking areas, also took violent forms. Such an incident was recorded in the Ghelnița commune (Trei Scaune county), where 70 villagers armed with clubs and hoes waited to meet the party car, and at the same time manufactured spare keys for the bell tower in case the bell ringer was arrested. However, the violence had already started to spread after some local priests were arrested, but only in isolated cases.

The same commune was a venue for an Easter pilgrimage, attended by several party members and the wives of some important state officials. Incidents also occurred in Târgu Secuiesc (Trei Scaune county), where PMR members received threats from the clergy. ${ }^{80}$ The ambivalence of some party members has already been proven in other cases, therefore such events did not come unexpected. There were also cases when opinion differed within a family, usually between the husband and wife. On the other hand, priests, when wholly supported by local communities, would go on the offensive to isolate party members. ${ }^{81}$

Anti-fascist actions, as part of Allied policies after the war, were used by the authorities to eliminate far-right manifestations. Anti-Semitism or xenophobia did not completely disappear from the social and cultural space, but merely from the public discourse. The legislation enacted after the 1948 Constitution severely punished such actions. The effort of discerning the truth in the midst of manipulation was however a difficult task. In a village from Trei-Scaune county, the Catholic priest was accused of spreading anti-Semitic ideas and Nazi books, while in Lunga commune (Trei Scaune county), 700-800 people attended the vespers $^{82}$ as the Securitate ${ }^{83}$ arrested a "chiabur" who illegally owned weapons. When trying to transport him to Covasna, the Securitate troops were stopped by 200 people who released the man. The Militia ${ }^{84}$ later arrived in the area, at which time the villagers were organizing a riot to protect the commune priest. The entire blame for the event was attributed to the reformed priest, while the Romanians who took part were later exonerated. ${ }^{85}$ Private ownership of weapons was entirely restricted and punishable under the law. Another riot subsequently took place in another predominantly Hungarian-speaking area. The taking into

80. Ibidem.

81. PMR members tasked with agitation and propaganda.

82. In Slavonic, the word "veceri" means evening. It is an evening prayer.

83. The General Directorate of the People's Securitate was established by Decree no. 221 of 30 August 1948. The usual name was Securitatea.

84. On 23 January 1949, the General Directorate of the Militia was established within the Ministry of the Interior (with the disbanding of the Police and Gendarmerie), with a specific structure and powers.

85. Collection C.C. of P.C.R, Propaganda and Sedition section, file 18/1949, f. 149. 
custody of some local priests was seen as an offence against the Hungarian people as a whole, hence the facts can be judged in that context. The creation of the Magyar Autonomous Region in 1952 will somewhat mitigate the social tensions.

The number of "sects" climbed from 60 to 300 (Brașov county) with the support of the Orthodox and Catholic churches, according to official data. Preachers from other regions went to the Jiu Valley, biblical quotations were written on the CFR cars, ${ }^{86}$ while in Șura-Mică commune (Sibiu county), the priest urged the villagers to pray as war would come in the next two weeks.

Official reports (the Făgăraș, Târgu Mureș or Cluj counties) mentioned financial support and prayers against the drought. The anti-fascist committee was deemed accountable for having prevented believers from taking part in religious services. ${ }^{87}$ Given the ideological war, financial support and religious services were essential in difficult times in order to defend positions, while the anti-fascist committee was merely a scarecrow that represented the regime's interests.

The note sent to the Sedition and Propaganda Section 88 included a statement that village intellectuals were attracted to religious cults. The church choirs were led by teachers from rural areas (Suceava region), and the personality of Prince Stephen the Great ${ }^{89}$ was evoked by combining both nationalist and religious imagery..$^{90}$ At the same time, the lower peasantry began to join Protestant cults (Năsăud county.) ${ }^{91}$

The administrative units that owned radios, such as Costesti district (Pitesti region), functioned throughout the week, but the radio station was switched off on Sunday mornings either to save electricity or due to power outages. ${ }^{92}$ The central authorities saw this as manifest sabotage against the week-end activities planned for the villagers.

An article in the Scanteia newspaper reported on the "snake cult" that was being practised in the United States, where a venomous snake farm three hours away from Washington D.C. allowed cultists to let themselves bitten by the snakes or consume their blood. The survivors were thought to be saints, while

86. Romanian Railways.

87. Collection C.C. of P.C.R, Propaganda and Sedition Section, file 18/1949, f. 149.

88. The Sedition and Propaganda Section was a structure of the Central Committee of the Romanian Workers' Party tasked with drafting the cultural policies during the Communist regime in Romania.

89. Prince of Moldavia (one of the Romanians' medieval states, then a historic province) during the Middle Ages (1439-1504), he remained a historic symbol thanks to the fight against the Ottoman Empire and the building of many churches and convents in northern Moldavia.

90. Collection C.C. of P.C.R, Propaganda and Sedition Section, file 10/1957, f. 87-88.

91. Ibidem, file 18/1949, f. 149.

92. Ibidem, f. 87-88. 
those who died did so for lack of faith. It was an example of mystical practices set against the official scientific dogma. ${ }^{93}$

The multitude of situations and data mentioned by party activists in official documents can mislead the reader, offering them with an image filled with too many factual details. However, my intention is to substantiate the conclusions and convey the social imaginary of that time. It goes without saying that the regime was not supported by most people in rural areas, and was seen as foreign to the realities of that world. This was another reason why some party members discreetly took part in church life. By separating itself from the national component from an ideological standpoint, the regime will have gained its legitimacy only when it migrated to what was later known as nationalcommunism. Undoubtedly, the central decision-makers were aware the only solution lied in a compromise, which promised a relative social harmony.

\section{Political and Social Actions of Communist Authorities}

Describing problems in official reports was not enough. The regime needed hard actions, but only had the required means after 1949.

The 6 July 1947 report of the Ministry of Intelligence (Arad County) set out the economic and political duties of religious denominations, that were to support the collection of produce, ${ }^{94}$ peaceful coexistence with "cohabiting nationalities," 95 or defending friendly relations with neighbouring states during religious services. The villagers were urged to comply with labour discipline and take part in the cultural and education events organized by the authorities. ${ }^{96}$ All these measures were intended to rally the cults behind the new ideological direction. The collection of produce from villagers was the prelude to the scourge of collectivization that was to begin in 1949. Assigning this task to the church authorities would have attracted the fury of the peasants, hence it is hard to believe such instructions were actually followed by the clergy.

In official documents, the activists recalled the main religious organizations that were deemed as threats to the state. These included "The Army of the Lord", which belonged to the Orthodox Metropolis of Sibiu, The Blaj United Metropolis Blaj and the "Former Magyar reactionary centre with the Bethlen college in

93. Scânteia, issue 1156 of 28 June 1948, p. 3-4.

94. After the Communist regime set in, it enforced agricultural quotas ranging from $20 \%$ to $60 \%$ of the household produce. They were lower for the poor and higher for midincome and high-income peasants. They were also enforced to indirectly pressure the villagers into renouncing their lands and join collective farms. They were dismantled after 1957, according to http://www.rador.ro/. [Accessed on 26 May 2020.]

95. Name used by the Communist regime to designate ethnic minorities.

96. Collection Ministry of National Propaganda, file 2951/1946-1948, f. 65. 
Aiud." 97 They became enemies of the regime, with guidelines for the following period being thus set by the regime. The measures to "fight mysticism" or "religious propaganda" included conferences on various scientific topics in towns or villages, events that usually complemented health or illiteracy eradication campaigns.

Conferences such as "Science and Superstitions" or "Why People Speak Different Languages" were held at the University of Cluj. ${ }^{98}$

The authorities provided cultural alternatives intended to eradicate mysticism and illiteracy other regions as well (Bihor county.) ${ }^{99}$ A party report (Odorhei county) reminded that in the Catholic communes that organized the Ciuc pilgrimage, PMR led a joint action across several counties (Trei Scaune, Odorheiu and Ciuc) to prevent believers from travelling to this religious event. ${ }^{100}$

There were also reactions from the communities, so that when the priest would ask for money to pay his taxes, as it happened in Henig commune (Alba county), he was "exposed and the peasants no longer let him in their homes."101

The concerns of the authorities in response to religious activities included the endowment of libraries or the organization of "popular science conferences. ${ }^{102}$ Beginning with 1949, more activities were being organized to promote science and reject "mysticism and superstition." They were supported by newspaper articles or brochures in the CGM Cultural Book ${ }^{103}$ or the Cultural Digest. ${ }^{104}$ Short plays or conferences were also organized on such topics, with the support of party organizations.

One of the most important institutions tasked with promoting scientific socialism in the fight against religion was the "Society for the Promotion of Science and Culture" (SRSC), which followed the Soviet model of the "Union Association for the Promotion of Political and Scientific Knowledge."

"The Association for the Promotion of Science and Culture" was established by a decision of the Council of Ministers, issue 264 of 24 January 1949, and was

97. Ibidem, f. 66.

98. Collection C.C. of P.C.R, Propaganda and Sedition Section, file 18/1949, f. 164.

99. Ibidem, file 15/1948, f. 220.

100. Ibidem, file 18/1949, f. 56.

101. Ibidem, f. 123-125.

102. Ibidem, f. 164.

103. The General Labour Confederacy Publishing House was established in 1945. It published many collections of brochures: Engineering, Trade Union library, Soviet People at Work, Cultural Books, Theatre, according to https://aluiann.wordpress.com/. [Accessed 26 May 2020.]

104. The Cultural Vanguard was first published in Bucharest in 1949 and had a German version (Kultureller Wegweiser, led by the journalist Heinrich Simonis) and a Hungarian version (Müvelödes). It was intended as a guide for culture homes and was edited by the Nicolae Bălcescu culture home, according to https://ro.wikipedia.org/. [Accessed 26 May 2020.] 
subordinated to the Ministry of Arts. Its destination was to "promote science among the popular masses, fight obscurantism, mysticism and superstitions."105 The leadership consisted in a committee of 29 members, among which the literary historian Paul Cornea, the writer Geo Bogza and regime ideologists Leonte Răutu and Mihail Roller.

A transcript of a public conference held in Moscow by the central lecturer of the "Union Association for the Promotion of Political and Scientific Knowledge", published in the Pravda newspaper in 1951, titled "On the liquidation of religious relics in the minds of the people" was to establish the main directions of similar organizations in Romania. Its ideas included the "overcoming religious prejudices and all beliefs is part of the communist education of the working people", and "Religion is a form of social consciousness; it represents a fantastic and distorted reflection of reality". Moreover, "all religions admit and suggest to believers that there are good and bad supernatural beings who change people's lives and occupations for the better or worse."106

These were followed by public conferences on Marxism-Leninism, the printing of books and periodicals, radio shows, the displaying of slides and scientific films, and the organization of exhibitions. ${ }^{107}$

Moreover, a commission travelled to Suceava County, where Protestant cults had many believers, with the support of SRSC, which was to establish branches in all county seats and sub-branches in large enterprises. But the results were unsatisfactory by far, particularly in view of the intense activities expected during the winter, a season when farmers are less involved in agricultural work. References were made to the unsatisfactory "fighting against superstitions" during winter, when the focus was mainly on political and cultural activities, while shortcomings were addressed during bimonthly conferences. ${ }^{108}$ The poor results were due to both the superficial training of party cadres and the lack of well-organized cultural activities intended for the rural population.

In response to the annual Ciuc pilgrimage (Ciuc county), the authorities would organize several cultural and sports activities. These involved the local party branches (UTM, UFDR, UPM) and the Ministry of Arts. They included four local and national stages. There were also sports competitions under the "Youth Cup", with the final to be held in Bucharest.

The prizes were offered by the Ministry of Arts and included movie projectors, radio sets or books for the endowment of libraries. The Hungarianspeaking population was provided with entertainment by Hungarian State

105. Collection Association for the Promotion of Science and Culture, file 1/1951, f. 2.

106. Ibidem, file 32/1953, f. 39-41.

107. Ibidem.

108. Collection C.C. of P.C.R, Propaganda and Sedition section, file 7/1950, f. 180-181. 
Theatres, with the support of local newspapers. "Popular science conferences to fight mysticism" were also organized. 109

These efforts to thwart the religious pilgrimage were successful, according to official reports. As regards the number of participants, there were 3,500 spectators and 300 participants in the Gheorgheni division (Ciuc county) alone. The motorcycle contest (Ciuc county) was attended by more than 12,000 participants, and the final (Ciuc county) there were more than 15,000 people, who stayed to watch despite unrelenting rain. The contests also represented an occasion for the two communities to come together. UFDR organized "home art" exhibitions. The PMR reports mentioned a decrease in the number of believers participating in the Ciuc pilgrimage, from 70,000 in 1947 to 50,000 in 1948 and 25,000 in 1949. In order to secure achievement of the objectives, a growing number of activists were assigned in the county from the central Magyar school of the party, combined with the removal of those who failed to efficiently perform their tasks. ${ }^{110}$

In the Mureș county, although the Ciuc pilgrimage was prepared two weeks in advance, the party's actions caused a decline of participants to 200 from 800 in previous years. ${ }^{111}$

Heartened by the satisfactory results, the party organization leaders received further tasks. The main objective was to remove the influence of the Catholic religion on the peasantry by isolating Bishop Aron Marton, ${ }^{112}$ who was an enemy of the regime. ${ }^{113}$ The Catholic bishop was "exposed" and thus an outlaw for the regime, but was still supported by Catholic believers, so that manifestos were spread the Cristur square (Ciuc county) asking believers to take a stand on his behalf, with demonstrations also organized for that purpose. The reports mentioned that "triumph arches were made" or "mostly youths took part, who were made to swear they will protect the faith."114 The Catholic youth, despite taking part in state-sponsored events, kept their loyalty for the religious leaders in an act of cultural-religious compromise. As far as the party activists conveyed the information, exaggeration was part of the norm.

Religious leaders were arrested in an overt attempt to intimidate believers. In Alba county, two Baptist preachers were "exposed" and taken in custody in the Benic and Mihalț communes, who arrived there from other area (Turda town), on allegations of supporting American interests. As a result, 13 families who sought to join the Baptist cult renounced to do so. ${ }^{115}$

109. Ibidem, f. 186.

110. Ibidem, f. 187.

111. Ibidem, file 18/1949, f. 149.

112. See József Marton, Cartea Memorială Márton Áron la 100 de Ani de la Nașterea Sa (Marton Aron Memorial Book at 100 Years from his Birth) (Cluj-Napoca: Editura Gloria, 1996).

113. Collection C.C. of P.C.R, Propaganda and Sedition section, file 7/1950, f. 187.

114. Ibidem, file 18/1949, f. 149.

115. Ibidem, f. 123-125. 
The Cultural Vanguard magazine published 13 peace conferences, out of which two conferences were intended to fight "superstitions", and ten were scientific. In addition, the central press published articles defending the authorities' measures. These included "Vatican, an agency of American Imperialism" or "On superstitions, shakers and enchanted windows". The workers' clubs in cities and rural cultural homes were tasked with organizing such conferences.

County party committees trained activists and then worked in communes that had Protestant communities. All these were complemented by "exposing" actions, with the authorities gloating that "cultists left their sects."116

Hungarian publications also joined the fray. The party's report, "Certain Wrong Trends in the UPM Press Addressing Issues Concerning the Catholic Church and Clergy in Transylvania", mentioned the role of UPM publications in Transylvania that published written materials from the Catholic clergy or the "working people" on relations between the state and Catholic Church. The Nepujság newspaper of Târgu Mureș published 31 articles, while the Világosság of Cluj-Napoca published 22 articles in one calendar month. Praise was given to regime support in removing Vatican influence and in the fight for peace, but the mistakes made in public communication were also castigated.

The authorities feared a raising influence of Catholicism among the masses, since the newspaper articles showed appreciation and unwarranted interest for the Catholic clergy. ${ }^{117}$

Therefore, the newspaper Szabadzso of Timișoara, mentioned that "Catholic workers and priests are united for the defence of peace", while Világosság from Cluj-Napoca published a letter of a Cluj university professor regarding the contribution of the Catholic clergy, stating its admiration "for the standing of the Catholic Church, which has had a significant role in the life of our people". In Târgu Mureș, Nepujság quoted a collective letter of Catholic workers, who stated that "the Roman Catholic Church must find a way to join the fight for peace".

According to the same document, the Catholic clergy used Hungarianlanguage publications to obscure their past and build a new, positive image, as "some letters are meant to give certificates of good behaviour to priests".

The communist authorities resented that such letters were not "combative", avoided naming the "enemies of peace", and painted Catholic priests as "defenders of peace". They failed to "expose Imperialism and its accomplices in the Vatican."118

Rural cultural institutions were accused of failing to "contain the religious and mystical propaganda strongly promoted by the Church and various sects". The most vulnerable regions were Arad, Baia Mare, Suceva, Bucharest, Timișoara

116. Ibidem, file 7/1950, f. 211-212.

117. Collection C.C. of P.C.R, Propaganda and Sedition section, file 65/1950, f. 14-16.

118. Ibidem. 
or the Magyar Autonomous Region. ${ }^{119}$ The causes were said to be the poor quality of the science conferences and the insufficient "perceptive and visual" propaganda tools used in exhibitions or movies. All these provided a clear advantage to protestant cults, whose sound logistics, including the availability of establishments or the organization of brass music choirs, leveraged the "ignorance of an underdeveloped part of the peasantry."120

This led to proposals for measures such as "stepping up scientific propaganda" via the conferences organized by the SRSC, support from the UTM Central Committee, and clear position-taking by the regime relative to religion within party schools. The regional political lecturers were tasked with travelling to villages to "promote science and atheism."121

A 1951 report (Alba district) mentioned failures of SRSC conferences due to lack of logistical means, and proposed measures such stepping-up class struggle against regime opponents, as the latter kept "the working population in a the state of cultural backwardness, mysticism and superstition."122

Against this background, theatre plays were proposed by the Scânteia newspaper, which in the CGM Cultural Book no. 5 emphasized the cultural and educational materials of the publication. One example was the play "Don't Believe in Charms", by Russu-Șirianu Vintilă, which showed how a worker tried to convince the peasants of the importance of medicine instead of "charms and superstitions", with the latter eventually acknowledging the obvious superiority of science. This would later become a model for other theatre plays. ${ }^{123}$

The communist authorities employed a wide range of actions to deter what they called "religious propaganda", trying to provide alternative past-times such as science presentations or more practical events such as theatre plays, film screenings or various competitions. Concurrently, the regime also enforced coercive measures ranging from pressure on religious communities to public "exposures", followed by arrests of religious leaders. However, all these actions, as I will later show in the conclusions, amounted to barely a few gains for the regime at local level, and none at national level.

\section{Conclusion}

In spite of the communist regime's efforts to impose its own cultural agenda relative to mass cultural policies, the effects were somewhat overdue, and the

119. See Stefano Bottoni, Stalin's Legacy in Romania. The Hungarian Autonomous Region, 1952-1960 (New York, London: Lanham, Boulder, 2018).

120. Collection C.C of P.C.R, Propaganda and Sedition Section, file 33/1958, f. 137.

121. Ibidem, file 10/1957, f. 87-88.

122. Collection Regional Committee P.M.R Alba, file 1/1951, f. 18.

123. Scânteia, issue 1156 of 28 June 1948, p. 3-4. 
results were rather modest. Romania's forced development was met with the inherent problems of modernization and industrialization. The forced imposition of a foreign ideology to a rather conservative Eastern European area relying on obsolete mindsets, in a society where $80 \%$ of the population lived in rural areas as of the end of the Second World War, required a longer period of time than the regime had originally planned.

The rural population was definitely reluctant to embrace the new atheist ideology for several reasons. First, the Church still held considerable influence on the education, health conceptions and on people's lives in general. Priests still enjoyed a privileged status and, next to teachers, made up the intellectual rural elite. A partial uncoupling from rural traditions will only come about after mass migrations to industrial cities in need of labour. In no way would the new "town people" and industrial workers become "new people" as the regime heralded at the beginnings of the cultural revolution, but some deep social and cultural changes were definitely bound to happen.

The Communist regime, in spite of sustained anti-religious campaigns, achieved only modest results in the secularization of the society and culture. Interestingly, many PMR members, although formally embracing the new ideology, seemed to remain discreetly involved in religious life. The secularization of a society is contingent on a lengthy process of gradual modernization. The communist regime took major steps through commendable efforts, including a successful literacy campaign, ${ }^{124}$ the establishment of many well-endowed libraries, especially in rural areas where they had been sorely missed, or disease eradication campaigns. But this phase of mass education needed time and particularly a more careful approach, which some communist leaders such as Gheorghe Gheorghiu-Dej understood from the beginning. This gave rise to a so-called "partnership" with the dominating Orthodox Church. The regime line adopted from the first days of power ensured, to a certain extent, its survival and subsequent earning of legitimacy.

The second phase of the Communist regime, which began with Nicolae Ceaușescu taking power, a nationalist leader who would build what was later called national communism, also saw the uprooting of religious symbols, with Santa Claus becoming Moș Gerilă, and the Christmas tree becoming the "winter tree."125

This state of fact will be maintained, with various changes between periods, until the end of the Communist regime. The post-communist period marked a return to religious life, particularly in Orthodox countries, somewhat similar to

124. See Alin Goron, "Alfabetizarea în Cadrul Educației Adulților sub Regimul Comunist 1948-1956" (Alphabetization of Adults during the Communist Regime 19481956) B.C.S..S, no. 24 (2018): 239-265.

125. See Tom A. Jerman, Santa Claus Worldwide: A History of St. Nicholas and Other Holiday Gift-Bringers (Jefferson, NC, USA: McFarland \& Co Inc, 2020), 199. 
what happened in Russia. ${ }^{126}$ This was due to the insecure economic and social situation after the fall of Communism, a transition which left deep scars. Then, a rise in living standards, particularly in the latter decade, mainly due to an increase in consumption, embarked Romanian society on a process of steady secularization.

Today, most Romanians declared themselves as Christian Orthodox, although few of them are practising this religion. Most of those who regularly attend Church service are in their sixties, and some are former members of the Communist party. Public atheism remains a controversial topic, particularly in relation to public persons, and many young people are agnostic and at the same time openly critical of the authoritarianism of the Orthodox Church. ${ }^{127}$

The public space is currently subject to a dispute between the defenders and opponents of two major subjects: the maintenance or the elimination of the study of religion in public schools, and the introduction of sex education in schools. Today, these topics paint the picture of a modern society that is taking significant steps towards secularization.

\section{Bibliography}

Bottoni, Stefano. Stalin's Legacy in Romania. The Hungarian Autonomous Region, 1952-1960. New York, London: Lanham, Boulder, 2018.

.Transilvania Roșie. Comunismul Român şi Problema Națională 1944-1965. (Red Transylvania. Romanian Communism and the National Problem 1944-1965.) ClujNapoca: Editura Institutului Pentru Studierea Problemelor Minorităților Naționale, 2010.

Deletant, Dennis. Hitler's Forgotten Ally: Ion Antonescu and His Regime, Romania 1940-1944. Houndmills, Basingstoke, Hampshire and New York: Palgrave MacMillan, 2006.

George, Richard T. D. And James P. Scanlan. Marxism and Religion in Eastern Europe. Dordrecht-Holland and Boston: D. Riedel Publishing Company, 1974.

Gilberg, Trond. "Religion and Nationalism in Romania." In Religion and Nationalism in Soviet and East European Politics, edited by Pedro Ramet. Durham, N.C.: Duke Press Policy Studies, 1984.

Goron, Alin. "Alfabetizarea în Cadrul Educației Adulților sub Regimul Comunist 19481956" (Alphabetization of Adults during the Communist Regime 1948-1956.) B.C.S.S., no. 24 (2018): 239-265.

Institutul Cultural Roman. Religion and Identity in Interwar Romania: Orthodoxism. Retrieved from: https://www.icr.ro/pagini/religion-and-identity-in-interwar-romania-orthodo xism. [Accessed 19 May 2020.]

126. See Sonja Luehrmann, "Evolving Soviet Atheist Critiques of Religion and why they Matter for Anthropology," 2015.

127. See Lucian Turcescu and Lavinia Stan, "Religion, Politics and Sexuality in Romania," Routledge, Europa-Asia Studies 57, no. 2 (2005): 291-310. 
Jerman, Tom A. Santa Claus Worldwide: A History of St. Nicholas and Other Holiday GiftBringers. Jefferson, NC, USA: McFarland \& Co Inc, 2020.

Jowitt, Kenneth. Social Change in Romania, 1860-1940, A Debate in Development of a European Nation, Institute of International Studies. Berkeley: University of California, 1978.

King, Robert R. "Religion and Communism in the Soviet Union and Eastern Europe." BYU Studies Quarterly 15, no. 3 (1975): 323-347.

Kotkin, Stephen. Magnetic Mountain. Berkeley, Los Angeles, London: University of California Press, 1995.

Kurian, K. Mathew. "Marxism and Christianity." Social Scientist 2, no. 8 (1974): 3-21.

Leuștean, Lucian N. Orthodoxy and the Cold War Religion and Political Power in Romania, 1947-1965. Basingstoke, Hampshire and New York: Editura Palgrave Macmillan, 2009.

Livezeanu, Irina. Cultural Politics in Greater Romania: Regionalism, Nation Building, and Ethnic Struggle, 1918-1930. Cornell University Press, 1995.

Löwy, Michael and Mariana Ortega Brena. "Communism and Religion: José Carlos Mariátegui's Revolutionary Mysticism." Latin American Perspectives 35, no. 2 (2008): 71-79.

Luehrmann, Sonja. "Antagonistic Insights: Evolving Soviet Atheist Critiques of Religion and why they Matter for Anthropology." Social Analysis: The International Journal of Anthropology 59, no. 2 (2015): 97-113.

Magdó, Zsuzsánna. "Mass Enlightenment, Atheism and the Romanian Socialist Nation: The Society for Dissemenation of Culture and Science, 1949-1963." In Politici Culturale și Modele Intelectuale în România, edited by Lucian Năstasă and Dragoș Sdrobiș. ClujNapoca: Editura Mega, 2013.

Marton, József. Cartea Memorială Márton Áron la 100 de Ani de la Nașterea Sa (Marton Aron Memorial Book at 100 Years from his Birth.) Cluj-Napoca: Editura Gloria, 1996.

McLellan, David. Marxism and Religion. Houndmills, Basingstoke, Hampshire and London: MacMillan Press, 1987.

Molloy, Peter. The Lost World of Communism, An Oral History of Daily Life Behind the Iron Curtain. BBC Books, 2017.

National Central Historical Archives. Collection Central Committee of the Romanian Communist Party, the Propaganda and Sedition Section.

National Central Historical Archives. Collection Ministry of National Propaganda.

National Central Historical Archives. Collection The Society for the Promotion of Science and Culture.

The Alba County Service of the National Archives. Collection Rayonal Committee of the Romanian Communist Party.

Turcescu, Lucian and Lavinia Stan. "Religion, Politics and Sexuality in Romania." EuropaAsia Studies 57, no. 2 (2005): 291-310.

Vasile, Cristian. Biserica Ortodoxă Română în Primul Deceniu Comunist. (The Romanian Orthodox Church during the First Communist Decade.) București: Editura Curtea Veche, 2013.

. Intre Vatican si Kremlin. Biserica Greco-Catolică in Timpul Regimului Comunist (Between Vatican and the Kremlin. The Greek Catholic Church during the Communist Regime.) București: Editura Curtea Veche, 2013. 